\title{
PEMBINAAN PASIEN PENYAKIT KRONIS (P3KL) \\ PADA KELOMPOK MASYARAKAT PROLANIS MELALUI EDUKASI MANAJEMEN DIABETES MELITUS
}

\author{
Iin Patimah ${ }^{1}$, Iwan Wahyudi, Susan Susyantie, Tantri Puspita, Tanti Suryawantie, \\ Yayang, Yusti, Gani \\ 1,2,3,4,5Program Studi Profesi Ners STIKes Karsa Husada Garut \\ Jln. Nusa Indah no. 24 Garut Jawa Barat \\ e-mail: iin.patimah84@gmail.com
}

\begin{abstract}
ABSTRAK
Diabetes mellitus (DM) masih menjadi masalah kesehatan khusunya di Indonesia dan mejadi 5 besar penyakit penyebab kematian. Pengetahuan terkait pencegahan maupun penatalaksanaan diabetes perlu diperkenalkan kepada masyarakat agar menjadi bekal dalam membuat keputusan tindakan apa yang harus dilakukan untuk menghindari berbagai macam komplikasi penyakit sebagai dampai dari penatalaksanaan penyakit DM yang buruk maupun terlambat. Tujuan dari kegiatan ini adalah untuk memberikan pengetahuan kepada masyarakat mengenai penyakit DM dan penatalaksanaan. Metode yang digunakan adalah penyuluhan langsung bertatap muka dengan peserta prolanis melalui media audio visual, power point dan leaflet serta evaluasi berupa instrument pengetahuan tentang DM yang berjumlah 15 pertanyaan. Hasil yang didapatkan menunjukan bahwa, dari 55 peserta setelah dilakukan edukasi, 35 peserta menunjukan pengetahuan yang baik (63\%) dan 20 orang (37\%) dalam kategori pengetahuan cukup. Diperlukan program edukasi yang berkesinambungan kepada masyarakat terkait pengenalan penyakit kronis salah satunya DM
\end{abstract}

\section{Kata Kunci: Edukasi, Diabetes Melitus, Penyakit Kronis, Prolanis.}

\begin{abstract}
Diabetes mellitus is still a particular health problem in Indonesia and has become the top 5 disease causing death. Knowledge regarding diabetes prevention and management needs to be introduced to the public so that they are can make decisions what actions should be taken to avoid complications of the disease as a result of poor or late management of DM. The purpose of this activity is to provide knowledge to the public about DM and its management. The method used is direct counseling face to face with the patient's DM or the other Chronical illness like Hypertension and many more. Media education used visual media, power points and leaflets and evaluation in the form of knowledge instruments about $D M$, amounting to 15 questions. The results obtained showed that, of the 55 participants education, 35 participants showed good knowledge (63\%) and 20 people $(37 \%)$ in the category of sufficient knowledge. A continuous education program is needed for the community related to the introduction of chronic diseases, one of which is DM
\end{abstract}

\section{Keyword: Diabetes, Education, Chronical Illness, Prolanis}




\section{PENDAHULUAN}

Dari tahun 2010 - 2018 usia harapan hidup masyarakat indonesi meningkat, tahun 2018 usia harapan hidup mencai 71.2, yang berarti bayi yang dilahirkan dapat mencapai usia 71,2 tahun (Badan Pusat Statistik, 2017). peningkatan harapan hidup selayaknya diiringi dengan kualitas hidup masyarakat yang baik, namun kenyataannnya peningkatan harapan hidup diiringi dengan penurunan kualitas hidup salah satu factor penyebabnya adalah penurunan derajat kesehatan seseorang. Berbagai masalah kesehatan yang dihadapi saat ini adalah tingginya angka kejadian penyakit kronis salah satunya Diabetes Melitus (DM), tahun 2030 World Health Organization (WHO) diestimasikan penduduk Indonesia akan mengalami DM sebanyak 21.3 juta (Kementrian Kesehatan, 2019). DM atau dikenal masyarat sebagai penyakit kencing manis merupakan masalah kesehatan masyarat yang umum ditemui saat ini dan menjadi 5 besar penyakit diindonesia sebagai penyebab tingginya angka kesakitan dan kematian (Kosti \& Kanakari, 2013). Oleh karena itu diperlukan pencegahan maupun penanganan secara dini untuk menghindari berbagai macam komplikasi yang dapat meningkatkan angkat mortalitas akibat DM. disanalah pentingnya edukasi sebagai bekal dalam penanganan penyakit DM. edukasi merupakan suatu usaha untuk memberikan berbagai informasi yang digarapkan dapat berfungsi sebagai navigator dalam pengambilan keputusan, pemecahan masalah, aktif bekerja sama dengan tim, memahami arti kesehatan, peningkatan self efficacy peningkatan status kesehatan dan kualitas hidup (Funnell et al., 2011; Smith et al., 2019; Krall et al., 2016). Edukasi menjadi bagian penting dalam manajemen diabetes mellitus hal ini diperkuat dari berbagai hasil riset terkait bahwa edukasi meilki pengaruh dalam meningkatkan manajemen diri maukpun keluarga dalam pengelolaan penyakit DM. (Komang Riyon Ningrat \& Ulfiana, 2013; RIZA, 2011; Iin Patimah, Iwan Wahyudi, 2018; ).

Berdasarkan hal di atas, kami mengadakan kegiatan pengabsian masyarakat (abdimas) Pembinaan Pasien Penyakit Kronis (P3KL) pada kelompok Masyarakat Pogram pengelolaan penyakit krnis (Prolanis) melalui Edukasi Manajemen Diabetes Melitus.

\section{METODE}

Kegiatan ini dilakukan di gedung pertemuan Puskesmas Siliwangi Kab. Garut. Kegiatan ini diikuti oleh 55 peserta yang metode yang digunakan yaitu edukasi masyarakat melalui metode penyuluhan langsung

1. Memberikan edukasi kepada dengan metode penyuluhan

2. Evalusi dengan instrument kuesioner dan observasi.

\section{HASIL dan PEMBAHASAN}

Kegiatan pengabdian masyarakat yang telah dilakukan, terdiri dari beberapa rangkaian kegiatan, dimulai dari kegiatan persiapan, pelaksanaan dan evaluasi kegiatan. Pada tahapan persiapan, tim pengabdian masyarakat menyiapkan beberapa peralatan dan instrument yang diperlukan dalam kegiatan inidiantaranya: pembuatan media pembelajaran, SAP, izin kegiatan abdimas, serta leaflet yang akan dibagikan setelah selesai kegiatan. Pada tahapan ini juga disusun instrument yang berguna untuk mengevaluasi materi yang disampaiakn, instrument terdiri dari 15 pertanyaan yang mencakup pengetahuan dasar terkait DM, Gizi pasien DM, olahraga pada pasien DM dan pengobatan rutin serta pemeriksaan gul darah rutin pasien DM. 
Tabel 1. Distribusi Frekuensi Pengetahuan sebelum edukasi

\begin{tabular}{llll}
\hline No & Pengetahuan & F & $\%$ \\
\hline 1 & Baik & 5 & $9 \%$ \\
2 & Cukup & 20 & $37 \%$ \\
3 & Kurang & 30 & 54 \\
& Total & 55 & $100 \%$ \\
\hline
\end{tabular}

Dari tabel 1 diatas dapat diketahui pengetahuan peserta sebelum dilakukan edukasi, dari 25 peserta sebagian kecil (30\%) peserta sudah memiliki pengetahuan yang baik dan sebagain besar memiliki pengetahuan yang cukup.

Tabel 2. Distribusi Frekuensi Pengetahuan setelah edukasi

\begin{tabular}{llll}
\hline No & Pengetahuan & F & $\%$ \\
\hline 1 & Baik & 35 & $63 \%$ \\
2 & Cukup & 20 & $37 \%$ \\
3 & Kurang & 0 & \\
& Total & 55 & $100 \%$ \\
\hline
\end{tabular}

Dari tabel 2 diatas dapat diketahui pengetahuan peserta setelah dilakukan edukasi, dari 55 peserta sebagian besar memiliki pengetahuan yang baik $(63 \%)$ dan hampir setengahnya $(37 \%)$ masih memiliki pengetahuan yang cukup. Dari hasil pengabdian masyarakat yang sudah dilakukan, pemberian edukasi mampu meningkatkan pengetahuan pasien mengenai diabetes mellitus.

Pengetahuan merupakan produk dari tahu setelah seseorang kontak dengan suatu obyek melalui berbagai macam indra tubuh.pengetahuan didapatkan dari proses edukasi baik formal maupun informal, dengan pengetahuan akan membentuk prilaku seseorang.

Tujuan dari eukasi kegiatan ini adalah merubah prilaku atau membentuk prilaku masyarakat terkait pengelolaan diabetes. Dengan edukasi yang dilakukan oleh tenaga kesehatan pengetahuan yang didapat merupakan pengetahuan yang benar dan membantu pasien, prilaku yang didasari oleh pengetahuan akan bersifat lebih langgeng dibandingkan tanpa dasar pengetahuan yang kuat (Khumayra \& Sulisno, 2012).

Edukasi pasien DM dilakukan oleh seseorang yang sudah ahli dibidangnya melalui palatihan educator DM, Bagian penting peran educator DM selai transfer pengetahuan juga berperan untuk mengidentifikasi motivasi individu, mengubah perilaku kemudian membantu menetapkan tujuan perilaku yang dapat dicapai dan membimbing pasien dalam menghadapi melalui berbagai kendala (Khumayra \& Sulisno, 2012). Edukasi yang dilakukan oleh tim dosen STIKes karsa husada sudah memiliki sertifikat educator diabetes. Melalui edukasi ini beberapa manfaat yang dapat diambil oleh masyarakat dalam hal ini peserta mampu: mempelajari informasi dasar tentang diabetes dan manajemennya, peserta mampu mengaadopsi kebiasaan makan sehat melalui pendidikan nutrisi, memantau glukosa darah dan pelajari cara menafsirkan dan merespons hasilnya dengan tepat

\section{KESIMPULAN DAN SARAN}

Pengabdian pada masyarakat yang sudah dilakukan di daerah binaan Puskesmas Siliwangi Kab. Garut ini sudah dilaksanakanan sesuai perencana yang disudah disusun sebelumnya. Dari hasil pengabdian masyarakat terdapat peningkatan pengetahuan dimana jumlah peserta yang memiliki pengetahuan baik meningkat dari 9\% menjadi $63 \%$. Media pembelajaran yang sudah dipersiapkan berupa leflet disosialisaikan ke seluruh pengunjung puskesmas melalui media poster yang di tempel di ruangan khususnya di ruang tunggu.

\section{UCAPAN TERIMA KASIH}

Ucapan terima kasih diberikan kepada pimpinan STIKes Karsa Husada Garut yang telah memberikan dana 
kegiatan pengabdian ini dan juga kepada pihak Puskesmas Siliwangi yang telah membantu pelaksanaan pengabdian masyarakat ini.

\section{DAFTAR PUSTAKA}

Badan Pusat Statistik. (2017). [IPG] Angka Harapan Hidup (AHH) menurut Provinsi dan Jenis Kelamin, 2010-2018. https://doi.org/10.1055/s-2008-1040 325

Iin Patimah, Iwan Wahyudi, S. S. (2018). Pengaruh Program Edukasi Manajemen Diabetes Melitus (Promedia) terhadap Parameter Metabolik pada Pasien Diabetes Melitus Tipe II di RSUD dr. Slamet Garut.

Kementrian Kesehatan. (2019). Hari Diabetes Sedunia Tahun 2018. Pusat Data Dan Informasi Kementrian Kesehatan RI, 1-8.

Khumayra, Z. H., \& Sulisno, M. (2012). PERBEDAAN PENGETAHUAN DAN SIKAP PERILAKU HIDUP BERSIH. 1, 197-204.

Komang Riyon Ningrat*, K., \& Ulfiana, E. (2013). EDUKASI LATIHAN KELUARGA DENGAN MEDIA BOOKLET DAN MANAJEMEN DIET PASIEN DIABETES MELLITUS. Ekp, 13(3), 1-9.

Kosti, M., \& Kanakari, M. (2013). Education and diabetes mellitus | Insight Medical Publishing. Health Science Journal. http://www.hsj.gr/medicine/educati on-and-diabetes-mellitus.php?aid=3 151

Krall, J. S., Donihi, A. C., Hatam, M., Koshinsky, J., \& Siminerio, L. (2016). The Nurse Education and Transition (NEAT) model: educating the hospitalized patient with diabetes. Clinical Diabetes and Endocrinology, 2(1), 1-6. https://doi.org/10.1186/s40842-0160020-1

Riza, Y. (2011). Pengaruh Edukasi
Personal Tentang Manajemen

Diabetes Melitus Terhadap Pengetahuan Dan Persepsi Pasien Diabetes Melitus Tipe Ii Di Poliklinik Khusus Penyakit Dalam Rsup. Dr. M. Djamil Padang Tahun 2011.

file://D:/IinStatistik/bahan/edukasi manajmen.html

Smith, C. A., Chang, E., Gallego, G., Khan, A., Armour, M., \& Balneaves, L. G. (2019). An education intervention to improve decision making and health literacy among older Australians: A randomised controlled trial. In $B M C$ Geriatrics (Vol. 19, Issue 1). https://doi.org/10.1186/s12877-0191143-x 